\title{
Études/Inuit/Studies
}

\section{Allen P. McCartney (1941-2004)}

Volume 28, numéro 2, 2004

Espaces-Lieux-Noms

Spaces-Places-Names

URI : https://id.erudit.org/iderudit/013217ar

DOI : https://doi.org/10.7202/013217ar

Aller au sommaire du numéro

Éditeur(s)

Association Inuksiutiit Katimajiit Inc.

Centre interuniversitaire d'études et de recherches autochtones (CIÉRA)

ISSN

0701-1008 (imprimé)

1708-5268 (numérique)

Découvrir la revue

Citer ce document

(2004). Allen P. McCartney (1941-2004). Études/Inuit/Studies, 28(2), 265-265.

https://doi.org/10.7202/013217ar d'utilisation que vous pouvez consulter en ligne.

https://apropos.erudit.org/fr/usagers/politique-dutilisation/ 


\section{IN MIEMIORIAMI}

\section{Allen P. McCartney}

(1941-2004)

Northern studies lost one of its most esteemed practitioners on June 15, 2004, with the death of Allen P. McCartney, who had suffered from Parkinson's disease for the last several years. He was 63 years old. His interest in the Arctic began as an undergraduate student at the University of Arkansas, when he studied the wartime internment of Aleuts in southeastern Alaska. His first field work came in 1962, when he took part as a student worker on an archaeological project in the Nikolski village area in the eastern Aleutian Islands under the direction of William Laughlin, then of the University of Wisconsin. He received his M.A. and Ph.D. degrees from Wisconsin in 1967 and 1971. His work in the Aleut region continued over the next 40 years and included archaeological surveys throughout the Aleutian Islands as well as major excavations on the Alaska Peninsula, Unalaska Island, and St. Paul Island. He also pursued archaeological research in the Canadian Arctic. In addition to studying the Thule culture, he developed an extensive guide to the analysis of whale bone remains. More recently, he was involved in research on prehistoric whaling cultures in north Alaska.

Allen McCartney served as Professor of Anthropology at the University of Arkansas from 1970 until his retirement in 2003. Over his career, he produced numerous publications and conference papers. He wrote extensively about maritime adaptations, whale hunting peoples, prehistoric use of iron, cultural ecology, and AleutRussian contact. He served as editor of the journal Arctic Anthropology for 13 years; a soon to be released issue of that journal honours his contributions to northern scholarship. He received the Alaska Anthropological Association's Professional Achievement Award in 2003. (Source: Douglas W. Veltre) 